\title{
The Relationships of Problem-Solving, Anger Expression and Control, Self-Reflection and Insight of Prospective and In-Service Teachers
}

\author{
Ala Petrulyté ${ }^{1}$, Julita Navaitiené $\dot{2}^{2}$ Vaiva Rimiené $\dot{3}^{3}$ \\ Vytautas Magnus University, K. Donelaičio g. 58, LT-44248 Kaunas, ala.petrulytė@vdu.lt \\ Vytautas Magnus University, K. Donelaičio g. 58, LT-44248 Kaunas, julita.navaitiene@vdu.lt \\ Vytautas Magnus University, K. Donelaičio g. 58, LT-44248 Kaunas, vaiva.rimienė@vdu.lt
}

\begin{abstract}
The article presents the research on relations of problem-solving, anger, self-reflection of prospective and in-service teachers. The research within the sample of Lithuanian teachers disclosed positive correlations between their rationality in problem-solving, self-reflection, and anger control as well as between anger expression and emotionality in problem-solving. The regression analysis allowed stating that emotionality, rationality, need for self-reflection, and insight can help to forecast the expression of anger index.
\end{abstract}

Keywords: teachers, problem-solving, anger expression and control, self-reflection.

\section{Introduction}

Many European countries including Lithuania have been or will be soon facing a crisis in education, where the aging of teachers, their burnout syndrome of high level, and insufficient numbers of teacher recruits have been observed (TALIS, 2018). Possibly this is due to the specifics of teacher's profession which involves a high level of psychoemotional competences, which are needed in the communication with education community members. Merkys and Balčiūnas (2019) state that there is a massive shortage of teachers and educational support specialists in the country and they will become increasingly scarce in the future. Teachers do not tend to come to school, because this 
workplace is not attractive, and this work contains emotional strain and stress (TALIS, 2018; Merkys \& Balčiunnas, 2019). The relevant research would be closely related to the teacher's mental health, their emotional and social competences, especially in dealing with situations of anger and stress. In the opinion of the authors of this study, teachers' abilities of anger control, problem-solving and self-reflection are important in enhancing the quality of their work and can be improved by attending various professional development programmes.

The research on the State of General and Didactic Competences of Teachers in Lithuanian General Education Schools (2017) emphasized an insufficient level of these competences and a strong need for their improvement. The research on teachers' problem-solving, anger expression and control, self-reflection, and insight would help to understand the manifestations of competences and abilities of in-service and prospective teachers. The following scientific research problem was formulated: is there a correlation between problem-solving, anger expression and control, self-reflection and insight of in-service and prospective teachers, and what is the nature of this correlation? The goal of the research was to investigate relationships between problem-solving, anger expression, and control, self-reflection, and insight of in-service and prospective teachers.

\section{Theoretical problem analysis}

The ability could be defined as the performance of complex acts with ease, precision, and adaptability (Counell et al., 2003). Our research is based on the Triarchic Theory of Human Intelligence because it outlines the implications of the theory for skill training. Proposed by Robert J. Sternberg (1985), the theory contends that there are three types of abilities: (1) practical (the ability to get along in different contexts); (2) creative (the ability to come up with new ideas); and (3) analytical (the ability to evaluate information and solve problems) ones. The Triarchic Theory would most likely explain the practical, creative, and analytical weight of problem-solving, anger expression and control, selfreflection and insight abilities. The framework of these three abilities can take its own place in the list of teacher's abilities. The analysis of the document "Supporting teacher competence development for better learning outcomes" (European Commission, 2013) allows concluding that the abilities of EU teachers are of great importance to achieving better learning outcomes of school students. The fact that some teachers' abilities are more or less related to their effectiveness (Bardach \& Klassen, 2020) has resulted in a considerable interest in teachers' problem-solving, anger expression and control, selfreflection, and insight over the past decades.

The ability of problem-solving is one of the high-level abilities that are necessary for teachers, who have to address all the emerging challenges in their professional field. Orgoványi-Gajdos (2016) claims that the ability to deal with problems is the most essential 
feature in the teacher's profession because teaching consists of practical problems, which have to be solved (usually immediately). The problems encountered by teachers most frequently emerge in situations, when learners have to apply the possessed knowledge completing new assignments and to learn radically new things, when they have to consider different needs of their learners, to solve conflicts in a constructive way, to manage their class, to assess their learners' achievements, etc. All the professional activities starting with lesson planning and finishing with self-reflection on activities can be regarded as problem-solving. The researchers investigated expression of teachers' problem-solving abilities (Saadati et al., 2018; Santos-Trigo and Reynes-Martinez, 2019; Felmer et al., 2019; Bubnys, 2012). Saadati et al. (2018) analysed how teachers evaluate their own ability to solve problems and their value in the professional activity. Santos-Trigo and Reynes-Martinez (2019) conducted the research on expression of problem-solving among prospective teachers of mathematics and confirmed the necessity to improve methods of problem-solving. The problem-solving ability is not related to any special pedagogical competence as it is connected to all the key competences of teachers. OrgoványiGajdos (2016) characterizes problem-solving of teachers as interdisciplinary and suggests possible curriculum for developing problem-solving abilities. Felmer et al. (2019) confirmed the importance of problem-solving ability for professional development of prospective teachers. While solving the problems in the professional activity, teachers do not always consider the encountered problem in a rational way. They frequently experience an intensive sense of anger but express it in less adaptive behavioural patterns (Arbinaga, 2017; Kahneman, 2011; Spielberger, Reheiser and Sydeman, 1995; Spielberger, 1999). The researchers argue that professional stress and negative emotions have been accompanying contemporary teachers more and more often (Chan et al., 2010; Papathanasiou et al., 2015; Tahseen, 2015; Opeyemi, 2016; Tsivgiouras et al., 2019). On the basis of data provided for in the European Social Survey, Lithuanian teachers more frequently experience negative emotions compared to teachers from other European countries. Teachers suffer from an increased level of professional stress, which is caused by constant innovations, transformations in educational systems, social, demographic, organizational, and other changes (Bubeliené \& Merkys, 2010). The stress damages not only teachers' physical and psychical health but also has impact on learners and their environment (Chan et al., 2010). Stress experienced by teachers is defined as a response to various negative factors in professional activities and is linked to frequently accompanied anger (Howard, Johnson, 2004; Chan et al., 2010). Burić and Frenzel (2019) acknowledge that anger is the usual emotion for a teacher. According to Roulston et al. (2005), teachers with longer working experience are slightly less vulnerable to stress.

Anger expression (intensity, duration, frequency) and control are presented as important indicators of psychological health and wellbeing (Pukinskaitė \& Guogienè, 2010; Spielberger et al., 1995; Spielberger, 1999). Other aspects of teachers' negative emotions and experience were also investigated (Navaitiené, 2018; Petrulyte et al. 2017; Taxer 
et al., 2019). While evaluating the quality of teachers' work, anger control is regarded as a necessary aspect, but strong internal anger control may reduce teachers' ability to make constructive decisions in problem situations (Spielberger et al., 1995). The individuals, who tend to strongly control their emotions and actions, may feel anxiety, resentment, and anger (Ellis and Tafrate, 2005).

Reflecting on their own professional activity and engaging into self-reflection practice, levels of negative emotions tend to decrease (Huang, Lee, Frenzel, 2020; Seitova, 2019; Nystrup, 2019). In the course of self-reflection process, certain prerequisites are established that regulate actions, thoughts, and emotions of an individual as well as origins of these prerequisites. The meaning of prerequisites is doubted, and alternative behaviour is created. According to Taylor and Newberry (2018), understanding of emotional experience is more important than regulation of emotions as this leads to the reduced level of experienced negative emotions. Davis and McDonald (2019) revealed that the process of self-assessment through self-reflection had a bigger influence on teachers' professional development than evaluation given by external reviewers. Nystrup (2019) suggests that teachers seek consciousness; they are willing to enhance their self-awareness, regain emotional balance, and develop the ability to spend every day at school with clear thinking not obscured by emotions. In their research, Körkkö, Kyrö-Ämmälä and Turunen (2016) revealed development and deepening of written reflections of prospective primary teachers during their teaching practice and emphasised a positive influence of developing self-reflection ability on their professional development. The significance of self-reflection to the teacher's professional development and personality growth is highlighted by Farrell (2018), Seitova (2019), Žibienienè and Barkauskaite (2018), Civitillo et al. (2019), Soemantri et al. (2018), Bubnys (2012), Silvia and Phillips (2011), Stein and Grant (2014).

The overview of previous research allowed concluding that although teachers' problem-solving, anger, and self-reflection have been researched separately, the interrelationships and prediction possibilities of all these dimensions were not investigated sufficiently. The following research question arises: What are the relationships between the teachers' problem-solving, anger expression and control, self-reflection, and insight?

The goal of the research: to investigate relationships between the problem-solving, anger expression and control, self-reflection, and insight of in-service and prospective teachers.

\section{The research hypotheses:}

1. There exist positive relationships between the problem-solving, anger expression and control, self-reflection, and insight of teachers.

2. Teachers' emotionality in problem-solving and insight predicts their anger expression index.

3. There are differences in problem-solving, anger expression and control, selfreflection, and insight of in-service and prospective teachers. 


\section{The research methodology}

The survey was used as a method for collecting data in our quantitative research. The following three research instruments were applied: (1) Rational/Experiential Multimodal Inventory - REI-m (Pacini and Epstein, 1999); (2) State-Trait Anger Expression Inventory - STAXI-2 (Spielberger et al., 1999), and (3) Self-reflection and Insight Scale (Grant et al., 2002).

The inventory of problem-solving is grounded on Cognitive Experimental Self Theory (Epstein, 2003), which consists of 42 statements to be evaluated by respondents using the 5-point Likert scale, and two scales: Rationality and Experience. The scale of experience comprises the following three sub-scales: Emotionality, Imagination, and Intuition. Double translation of the instrument and a preliminary approbation of it was performed by Pukinskaitè and Guogienè (2010), and we were granted the permission from the authors to use the instrument in the survey. The Cronbach's alpha fluctuates from 0.8 and 0.87 (Petrulyte et al., 2017). In the present research the Cronbach's alpha of rational problem-solving scale is 0.79 , that of emotionality subscale equals 0.73 , the subscale of imagination - 0.7, and the Cronbach $\alpha$ of intuition sub-scale is equal to 0.74 .

The inventory of anger expression and control helps to identify the level of participants' anger and way of its expression. The inventory measures two indicators of anger (state-anger and trait-anger) and two ways of anger expression (anger control and anger expression) (Spielberger, 1999). The inventory of anger expression and control consists of 57 statements. Each statement was evaluated by the 4-point Likert scale considering how well it characterizes the anger the respondents' experience. The inventory comprises four scales and four sub-scales: 1. State Anger Scale, which measures the strength of anger as emotional, verbal or behavioural reactions. 2. Trait Anger Scale, which helps to evaluate the personality feature related to anger in various situations. 3. Anger Expression Scale measures the direction of anger and ways of its expression. The scale consists of two sub-scales: Anger Out Subscale, which helps to establish if the participants express their anger openly or if they direct it towards other people or objects in the surrounding environment; Anger In Subscale, which establishes the participants' intention to keep their anger within and not to reveal it to the surrounding people. 4. Anger Control Scale measures suppression and reduction of anger. This scale has two sub-scales: Anger-Control out Subscale, which reveals if participants make any attempts to express the anger they feel. Anger-Control in Subscale shows if participants try to suppress and reduce their anger. The description also helps to establish Anger Expression Index, which shows the strength of participants' anger and its possible expression through aggressive actions. The value of Cronbach's alpha of the description of anger expression and control is 0.84 (Spielberger, 1999). In this research, the Cronbach's alpha of anger description equals 0.79 (the scale of state-anger -0.88 , the scale of trait-anger- 0.84 , the subscale of anger in -0.70 . the subscale of anger control out -0.82 , the subscale of anger control in -0.86 , the subscale of anger control out -0.83 ). 
The scale of self-reflection and insight consists of 20 statements. The participants expressed their agreement/disagreement with the statements according to the 6-point Likert scale from "completely agree" to "completely disagree". The scale contains three sub-scales: (1) Engagement in Self-reflection Subscale, which measures the level of engagement of participants in self-reflection. (2) Need for Self-reflection Subscale, which shows the extent to which analysis and evaluation of own thoughts, feelings and behaviour are important to participants. (3) Insight Subscale, which discloses the participants' ability to understand their own thoughts, feelings and behaviour. Double translation of the instrument was performed by Navaitienè (2017), and we were granted the permission from the authors to use the instrument in the survey. The Cronbach's alpha fluctuates from 0.82 to 0.94 (DaSilveira et al., 2015; Aşkun \& Çetin, 2017). The Cronbach's alpha of the scale of self-reflection and insight equalled 0.82 (the subscale of Engagement in Self-reflection: 0.84 , the subscale of Need for Self-reflection: 0.77 , the subscale of Insight: 0.70 ). Since the Cronbach's alpha of all the three applied methodologies ranges from 0.70 to 0.88 , their internal consistency can be regarded as sufficient. The questionnaire of general data was compiled, where the respondents indicated their age, gender, and working experience.

The participants were the voluntary sample of prospective teachers (students of higher education schools and universities) and in-service teachers working in various Lithuanian schools. The prospective teachers were the teacher candidates who were enrolled in a teacher education programme and in their final year of education. They have very limited working experience gained during their teaching practice. The in-service teachers were the teachers with different working experience. These two groups of participants were singled out because the differences in problem-solving, anger expression and control, and self-reflection, and insight between the in-service and the prospective teachers were hypothesized. The total number of participants equalled 160 teachers: the average age of 94 prospective teachers ( 68 women, 26 men) was 20.3 years $(\mathrm{SD}=3.49)$ and that of 66 in-service teachers ( 45 women, 21 men) -48.8 years $(\mathrm{SD}=8.35)$. The age of 88 teachers ranged from 18 to 24 years. There were 8 teachers of $25-34$ years old, 18 teachers of 35-44 years old. The age of 27 teachers ranged from 45 to 54 years old and 19 teachers were older than 55 years. The working experience of three in-service teachers (out of 66) was 6-10 years, 10 teachers worked for 11-15 years, 2 participants had an experience of 16-20 years, 8 participants - 21-25 years and 30 teachers worked as teachers for more than 25 years. The remaining participants did not provide the related data.

The survey of prospective teachers was carried out in the autumn of 2019 with the verbal consent of the participants. The survey of in-service teachers was conducted in the autumn of 2019 and from January to February of 2020 after the lessons with the verbal consent of the participants.

The statistical methods of data processing: Kolmogorov-Smirnov and Shapiro-Wilk normality tests, Student's-t test for independent samples, Mann-Whitney U test, Spearman correlation test, regression analysis. 


\section{The research results}

\section{The results of research on teachers' problem-solving}

The distribution of data on problem-solving was in line with the normal distribution $(p>0.05)$. Therefore, parametric criteria were applied for analysis of problem-solving data. The differences in problem-solving data between prospective and in-service teachers were not identified. It was established that while solving problems (see Table 1) the participants-female teachers are guided by intuition more than their male colleagues $(\mathrm{p}=0.02)$.

Table 1

The Comparison of Mean Values of Problem-Solving of Male Teachers $(N=47)$ and Female Teachers $(\mathrm{N}=113)$

\begin{tabular}{llccccc}
\hline $\begin{array}{c}\text { Subscales of } \\
\text { problem-solving }\end{array}$ & Gender & $\begin{array}{c}\text { Mean } \\
\text { values }\end{array}$ & $\begin{array}{c}\text { Difference in } \\
\text { mean values }\end{array}$ & t & df & p \\
\hline Rationality & Men & 42.06 & 2.19 & 1.42 & 158 & .15 \\
& Women & 39.86 & & & & \\
\hline Emotionality & Men & 32.89 & -1.17 & -0.79 & 158 & .42 \\
& Women & 33.07 & & & & \\
\hline Imagination & Men & 34.17 & -1.92 & -1.32 & 158 & .19 \\
& Women & 36.09 & & & & \\
\hline Intuition & Men & 30.72 & -2.82 & -2.29 & 158 & $\mathbf{. 0 2}$ \\
& Women & 33.54 & & & & \\
\hline Experience & Men & 97.78 & -5.92 & -1.87 & 158 & .06 \\
& Women & 103.7 & & & & \\
\hline
\end{tabular}

\section{The results of research on teachers' anger expression and anger control}

The conducted normality test of data on teachers' anger expression and control revealed that the distribution of data on anger expression and control was not normal $(\mathrm{p}<0.05)$. Therefore, non-parametric statistical criteria were applied for further data analysis.

The comparison of anger expression and control among prospective and in-service teachers allowed concluding that external anger control $(\mathrm{p}=0.01)$ is stronger expressed among in-service teachers, whereas a higher anger expression index is typical of prospective teachers $(\mathrm{p}=0.05)$ (see Table 2$)$. 
Table 2

The Comparison of Value Ranks of Anger Expression and Control of Prospective

Teachers $(N=94)$ and In-Service Teachers $(N=66)$

\begin{tabular}{|c|c|c|c|c|c|}
\hline $\begin{array}{c}\text { Subscales of Anger } \\
\text { Expression and Control }\end{array}$ & Gender & Mean rank & Sum of ranks & $\mathrm{Z}$ & $\mathbf{p}$ \\
\hline State - anger & $\begin{array}{l}\text { prospective teachers } \\
\text { in-service teachers }\end{array}$ & $\begin{array}{l}72.22 \\
71.57\end{array}$ & $\begin{array}{l}6860.50 \\
3435.50\end{array}$ & -0.09 & .92 \\
\hline Trait - anger & $\begin{array}{l}\text { prospective teachers } \\
\text { in-service teachers }\end{array}$ & $\begin{array}{l}74.29 \\
67.46 \\
\end{array}$ & $\begin{array}{l}7058.00 \\
3238.00 \\
\end{array}$ & -0.93 & .35 \\
\hline Anger out & $\begin{array}{l}\text { prospective teachers } \\
\text { in-service teachers }\end{array}$ & $\begin{array}{l}72.54 \\
69.46 \\
\end{array}$ & $\begin{array}{l}6819.00 \\
3334.00 \\
\end{array}$ & -0.42 & .67 \\
\hline Anger in & $\begin{array}{l}\text { prospective teachers } \\
\text { in-service teachers }\end{array}$ & $\begin{array}{l}70.94 \\
72.60 \\
\end{array}$ & $\begin{array}{l}6668.00 \\
3485.00 \\
\end{array}$ & -0.22 & .81 \\
\hline Anger control out & $\begin{array}{l}\text { prospective teachers } \\
\text { in-service teachers }\end{array}$ & $\begin{array}{l}63.18 \\
87.80 \\
\end{array}$ & $\begin{array}{l}5938.50 \\
4214.50 \\
\end{array}$ & -3.38 & .01 \\
\hline Anger control in & $\begin{array}{l}\text { prospective teachers } \\
\text { in-service teachers }\end{array}$ & $\begin{array}{l}70.45 \\
73.56 \\
\end{array}$ & $\begin{array}{c}6622.0 \\
3531.00\end{array}$ & -0.42 & .66 \\
\hline Anger expression index & $\begin{array}{l}\text { prospective teachers } \\
\text { in-service teachers }\end{array}$ & $\begin{array}{l}75.28 \\
62.70\end{array}$ & $\begin{array}{l}7001.50 \\
3009.50\end{array}$ & -1.73 & .05 \\
\hline
\end{tabular}

The analysis of teachers' anger expression and control disclosed that the external anger of female participants is more expressed than that of male participants $(\mathrm{p}=0.05)$ (see Table 3$)$.

Table 3

The Comparison of Value Ranks of Anger Expression and Anger Control of Male

Teachers $(N=47)$ and Female Teachers $(N=113)$

\begin{tabular}{llcccc}
\hline $\begin{array}{c}\text { Subscales of Anger } \\
\text { Expression and Control }\end{array}$ & Gender & Mean rank & Sum of ranks & Z & p \\
\hline \multirow{2}{*}{ State-anger } & Men & 62.11 & 1118.00 & -0.77 & .44 \\
\hline Trait-anger & Women & 69.47 & 8198.00 & & .06 \\
& Men & 58.28 & 1049.00 & -1.18 & .06 \\
\hline Anger out & Women & 70.06 & 8267.00 & & \\
\hline Anger in & Men & 55.83 & 1005.00 & -1.42 & \multirow{2}{*}{$\mathbf{0 5}$} \\
& Women & 71.87 & 8175.00 & & \\
\hline Anger control out & Men & 70.72 & 1273.00 & -0.31 & .75 \\
& Women & 67.58 & 7907.00 & & \\
\hline Anger control in & Men & 75.72 & 1363.00 & -0.90 & .36 \\
& Women & 66.81 & 7817.00 & & \\
\hline Anger expression index & Men & 73.03 & 1314.50 & -0.58 & .55 \\
& Women & 67.23 & 7865.50 & & \\
\hline
\end{tabular}


The data presented in Table 4 show that the external anger control of in-service teachers is stronger expressed compared to that of prospective teachers $(\mathrm{p}=0.01)$. This complies with the overall results of sample, which were received comparing in-service and prospective teachers. Higher anger expression index is typical of prospective teachers compared to that of in-service participants $(p=0.02)$. This result complies with the findings of a general sample of teachers.

Table 4

The Comparison of Mean Ranks of Anger Expression and Control of Prospective $(N=68)$ and In-service $(N=45)$ Female Teachers

\begin{tabular}{llllll}
\hline $\begin{array}{c}\text { Subscales of Anger } \\
\text { Expression and } \\
\text { Control }\end{array}$ & \multicolumn{1}{c}{ Participants } & Mean rank & $\begin{array}{c}\text { Sum of } \\
\text { ranks }\end{array}$ & Z & p \\
\hline State-anger & $\begin{array}{l}\text { Prospective female teachers } \\
\text { In-service female teachers }\end{array}$ & 60.84 & 4258.50 & -0.53 & .59 \\
& Prospective female teachers & 63.21 & 4425.00 & -1.42 & .15 \\
& In-service female teachers & 54.08 & 2596.00 & & \\
\hline Trait-anger & Prospective female teachers & 62.07 & 4283.00 & -1.17 & .23 \\
& In-service female teachers & 54.58 & 2620.00 & & \\
\hline Anger out & Prospective female teachers & 58.46 & 4034.00 & -0.20 & \multirow{2}{*}{.83} \\
& In-service female teachers & 59.77 & 2869.00 & & \\
\hline Anger control out & Prospective female teachers & 49.46 & 3412.50 & -3.65 & $\mathbf{. 0 1}$ \\
& In-service female teachers & 72.72 & 3490.50 & & \\
\hline Anger control in & Prospective female teachers & 57.39 & 3960.00 & -0.61 & .53 \\
& In-service female teachers & 61.31 & 2943.00 & & \\
\hline Anger expression & Prospective female teachers & 64.38 & 4378.00 & -2.24 & $\mathbf{. 0 2}$ \\
& In-service female teachers & 50.17 & 2408.00 & & \\
\hline index & & &
\end{tabular}

\section{The results of research on teachers' self-reflection and insight}

The non-parametric criteria were used for the statistical data analysis because the normality assumption was rejected ( $\mathrm{p}<0.05)$. The comparison of self-reflection and insight of prospective and in-service teachers revealed that there is no difference in the values of engagement in self-reflection and the need for self-reflection of prospective teachers and in-service teachers $(\mathrm{p}>0.05)$. Statistically significant differences were identified only in the insight: higher values of insight were typical of in-service teachers compared to prospective teachers $(\mathrm{p}=0.01)$ (see Table 5$)$. 
Table 5

The Comparison of Mean Ranks of Self-Reflection and Insight of Prospective $(N=94)$ and In-service $(N=66)$ Teachers

\begin{tabular}{|c|c|c|c|c|c|}
\hline $\begin{array}{l}\text { Subscales of } \\
\text { self-reflection } \\
\text { and insight }\end{array}$ & Participants & Mean rank & Sum of ranks & $\mathbf{Z}$ & $\mathbf{p}$ \\
\hline $\begin{array}{l}\text { Engagement in } \\
\text { self-reflection }\end{array}$ & $\begin{array}{l}\text { Prospective teachers } \\
\text { In-service teachers }\end{array}$ & $\begin{array}{l}73.08 \\
69.85\end{array}$ & $\begin{array}{l}6943.00 \\
3353.00\end{array}$ & -0.44 & .65 \\
\hline $\begin{array}{l}\text { Need for self- } \\
\text { reflection }\end{array}$ & $\begin{array}{l}\text { Prospective teachers } \\
\text { In-service teachers }\end{array}$ & $\begin{array}{l}71.68 \\
72.64 \\
\end{array}$ & $\begin{array}{l}6809.50 \\
3486.50 \\
\end{array}$ & -0.13 & .89 \\
\hline Insight & $\begin{array}{l}\text { Prospective teachers } \\
\text { In-service teachers }\end{array}$ & $\begin{array}{l}61.83 \\
92.14\end{array}$ & $\begin{array}{l}5873.50 \\
4422.50\end{array}$ & -4.13 & .01 \\
\hline
\end{tabular}

Self-reflection and insight of the investigated men and women were compared. The results of comparison in terms of gender showed that engagement in self-reflection and need for self-reflection did not significantly differ between the female and male participants but the values in the scale of insight were statistically significantly higher among female teachers than those of male ones in the research $(p=0.04)$ (see Table 6).

Table 6

The Comparison of Average Ranks of Self-Reflection and Insight of Men $(N=47)$ and Women $(N=113)$

\begin{tabular}{llcccc}
\hline $\begin{array}{c}\text { Subscales of self-reflection } \\
\text { and insight }\end{array}$ & Gender & Mean rank & Sum of ranks & Z & p \\
\hline Engagement in self-reflection & Men & 71.17 & 1281.00 & -0.30 & .75 \\
& Women & 68.09 & 8035.00 & & \\
\hline Need for self-reflection & Men & 74.36 & 1338.50 & -0.67 & .49 \\
& Women & 67.61 & 7977.50 & & \\
\hline Insight & Men & 54.28 & 977.00 & -1.64 & .04 \\
& Women & 70.67 & 8339.00 & & \\
\hline
\end{tabular}

It was hypothesized that there are differences between problem-solving, anger expression and control, self-reflection, and insight of in-service and prospective teachers. The hypothesis was partly confirmed due to statistically significant differences in external anger control with stronger expression among in-service teachers, in anger expression index with higher values in prospective teachers, and in the insight with higher values of insight in in-service teachers. 


\section{The relationships of teachers' problem-solving, anger expression and control, self-reflection, and insight}

A relatively weak but statistically significant negative correlation was established between rationality in problem-solving and the majority of anger expression variables (see Table 7). Rationality positively correlated with external anger control $(\mathrm{r}=0.23, \mathrm{p}=0.04)$ and internal anger control $(\mathrm{r}=0.28, \mathrm{p}=0.01)$.

Table 7

The Correlations Between Teachers' Problem-Solving and Anger Expression and Control

\begin{tabular}{|c|c|c|c|c|c|c|}
\hline $\begin{array}{c}\text { Scale and subscales of } \\
\text { Problem-Solving and } \\
\text { Anger Expression and } \\
\text { Control }\end{array}$ & & Rationality & Emotionality & Imagination & Intuition & Experience \\
\hline \multirow{2}{*}{ State-anger } & $\mathrm{r}$ & -.21 & .02 & -.06 & .01 & -.01 \\
\hline & $\mathrm{p}$ & .01 & .73 & .46 & .90 & .09 \\
\hline \multirow{2}{*}{ Trait-anger } & $\mathrm{r}$ & -.28 & .27 & .02 & .12 & .20 \\
\hline & $\mathrm{p}$ & .01 & .01 & .77 & .14 & .01 \\
\hline \multirow{2}{*}{ Anger out } & $\mathrm{r}$ & -.17 & .20 & .11 & .01 & .20 \\
\hline & $\mathrm{p}$ & .03 & .04 & .83 & .84 & .14 \\
\hline \multirow{2}{*}{ Anger in } & $r$ & -.05 & .25 & .15 & .08 & .23 \\
\hline & $\mathrm{p}$ & .94 & .02 & .07 & .34 & .01 \\
\hline \multirow{2}{*}{ Anger control out } & $\mathrm{r}$ & .23 & -.18 & .14 & -.06 & -.05 \\
\hline & $\mathrm{p}$ & .04 & .02 & .08 & .46 & .53 \\
\hline \multirow{2}{*}{ Anger control in } & $\mathrm{r}$ & .28 & -.03 & .13 & .48 & .07 \\
\hline & $\mathrm{p}$ & .01 & .68 & .11 & .57 & .35 \\
\hline \multirow{2}{*}{$\begin{array}{l}\text { Anger expression } \\
\text { index }\end{array}$} & $\mathrm{r}$ & -.29 & .27 & -.03 & .04 & .13 \\
\hline & $\mathrm{p}$ & .01 & .01 & .70 & .58 & .09 \\
\hline
\end{tabular}

Statistically significant positive relationships were established between emotionality and trait-anger, external and internal anger expression, and anger expression index (see Table 7). The values of experience in problem-solving (total variable of emotionality, imagination, and intuition) and trait-anger as well as internal anger expression also disclosed a significantly positive correlation.

The teachers' external anger control (see Table 8) weakly correlated with the teachers' need for self-reflection $(r=0.225, p=0.007)$. Therefore, it is possible to assume that teachers with a stronger need for self-reflection also possess stronger external anger control. A weak correlation was also identified between the teachers' need for self-reflection and internal anger control $(\mathrm{r}=0.275, \mathrm{p}=0.001)$. This allows assuming that teachers with a stronger need for self-reflection also demonstrate stronger internal anger control. 
The teachers' need for self-reflection weakly negatively correlates with the index of anger expression $(r=-0.176, p=0.037)$ and it is possible to conclude that the participants with a stronger need for self-reflection have a weaker anger expression.

The anger of teachers as a trait correlates with their insight in a very weak negative way $(\mathrm{r}=-0.19 ; \mathrm{p}=0.02)$, whereas insight correlates with anger as a trait $(\mathrm{r}=-0.31 ; \mathrm{p}=0.01)$, external $(\mathrm{r}=-0.26 ; \mathrm{p}=0.01)$ and internal $(\mathrm{r}=-0.20 ; \mathrm{p}=0.01)$ anger expression in a weak negative way. The above-mentioned allows stating that teachers with stronger insight have weaker anger as a state and as a trait. Moreover, weaker external and internal anger expression is also characteristic of them. The teachers' insight weakly positively correlates with their external anger control $(r=0.20, p=0.01)$. It can be assumed that teachers who are characterized by stronger insight will also possess stronger external anger control. A weak negative correlation was observed between the teachers' insight and anger expression index $(\mathrm{r}=-0.33 ; \mathrm{p}=0.01)$. Therefore, it is possible to assume that teachers with stronger insight express their anger in a weaker manner.

Table 8

The Correlations between Teachers' Anger Expression and Control, and Self-Reflection and Insight

\begin{tabular}{|c|c|c|c|c|}
\hline $\begin{array}{l}\text { Scale and subscales of } \\
\text { Anger Expression and } \\
\text { Control, and Self- } \\
\text { Reflection and Insight }\end{array}$ & & $\begin{array}{l}\text { Engagement in } \\
\text { self-reflection }\end{array}$ & $\begin{array}{c}\text { Need for } \\
\text { self-reflection }\end{array}$ & Insight \\
\hline \multirow{2}{*}{ State-anger } & $\mathrm{r}$ & -.63 & .02 & -.19 \\
\hline & $\mathrm{p}$ & .45 & .80 & .02 \\
\hline \multirow{2}{*}{ Trait-anger } & $\mathrm{r}$ & -.07 & -.20 & -.31 \\
\hline & $\mathrm{p}$ & .56 & .28 & .01 \\
\hline \multirow{2}{*}{ Anger out } & $\mathrm{r}$ & -.04 & -.08 & -.26 \\
\hline & $\mathrm{p}$ & .59 & .30 & .01 \\
\hline \multirow{2}{*}{ Anger in } & $\mathrm{r}$ & .02 & .11 & -.20 \\
\hline & $\mathrm{p}$ & .81 & .17 & .01 \\
\hline \multirow{2}{*}{ Anger control out } & $\mathrm{r}$ & .03 & .22 & .20 \\
\hline & $\mathrm{p}$ & .67 & .01 & .01 \\
\hline \multirow{2}{*}{ Anger control in } & $\mathrm{r}$ & .13 & .27 & .08 \\
\hline & $\mathrm{p}$ & .11 & .01 & .30 \\
\hline \multirow{2}{*}{ Anger expression index } & $\mathrm{r}$ & -.09 & -.17 & -.33 \\
\hline & $\mathrm{p}$ & .24 & .03 & .01 \\
\hline
\end{tabular}

The data in Table 9 show that a weak correlation and a highly significant positive correlation are observed between the teachers' engagement in self-reflection and experience when solving problems $(r=0.37, \mathrm{p}<0.01)$ and with emotionality $(\mathrm{r}=0.34, \mathrm{p}<0.01)$ 
and imagination $(\mathrm{r}=0.33, \mathrm{p}<0.01)$. The assumption may be raised that the teachers, who tend to engage in self-reflection, employ their experience while solving problems. Moreover, imagination and emotionality in problem-solving are partial aspects of their engagement in self-reflection.

\section{Table 9}

The Correlations between Teachers' Problem-Solving and Self-Reflection and Insight

\begin{tabular}{lcccccc}
\hline \multicolumn{1}{c}{$\begin{array}{c}\text { Scales and } \\
\text { subscales }\end{array}$} & & Rationality & Emotionality & Imagination & Intuition & Experience \\
\hline Engagement in & $\mathrm{r}$ & .17 & $\mathbf{. 3 4}$ & $\mathbf{. 3 3}$ & .10 &. $\mathbf{3 7}$ \\
self-reflection & $\mathrm{p}$ & .41 & $\mathbf{. 0 1}$ & $\mathbf{. 0 1}$ & .20 & $\mathbf{. 0 1}$ \\
\hline Need for & $\mathrm{r}$ & $\mathbf{. 2 8}$ & $\mathbf{. 2 2}$ & $\mathbf{. 3 3}$ & .03 &. $\mathbf{2 6}$ \\
self-reflection & $\mathrm{p}$ & $\mathbf{. 0 1}$ & $\mathbf{. 0 1}$ & $\mathbf{. 0 1}$ & .65 & $\mathbf{. 0 1}$ \\
\hline \multirow{2}{*}{ Insight } & $\mathrm{r}$ & $\mathbf{. 2 2}$ & $\mathbf{- . 2 4}$ & -.02 & $\mathbf{. 2 6}$ & -.09 \\
& $\mathrm{p}$ & $\mathbf{. 0 1}$ & $\mathbf{. 0 1}$ & .76 & $\mathbf{. 0 1}$ & .27 \\
\hline
\end{tabular}

Teachers' need for self-reflection weakly positively correlates with rationality in problem-solving $(\mathrm{r}=0.28, \mathrm{p}=0.01)$, experience $(\mathrm{r}=0.26, \mathrm{p}=0.01)$, emotionality $(\mathrm{r}=0.22$, $\mathrm{p}=0.01)$ and imagination $(\mathrm{r}=0.33, \mathrm{p}=0.01)$. It allows assuming that teachers with a stronger need for self-expression employ rationality, emotionality, imagination, and experience when solving problems.

Teachers' insight is weakly positively related to rationality in problem-solving $(\mathrm{r}=0.22$, $\mathrm{p}=0.01$ ), which allows assuming that teachers with stronger insight are able to solve the encountered problems in a more rational way. Teachers' insight is weakly negatively linked to emotionality in problem-solving $(\mathrm{r}=-0.24, \mathrm{p}=0.01)$. This makes it possible to assume that teachers with stronger insight tend to avoid solving problems in an emotional way. A weak positive correlation was established between teachers' insight and intuition in problem-solving $(\mathrm{r}=0.26, \mathrm{p}=0.01)$. Therefore, teachers with stronger insight tend to rely on intuition more when solving problems.

It was hypothesized that there exist positive relationships between the problem-solving, anger expression and control, self-reflection, and insight of teachers. The hypothesis was partly confirmed due to statistically significant correlations between teachers' rationality, emotionality and experience in problem-solving and anger expression and control, while teachers' imagination and intuition in problem-solving had no statistically significant correlations with anger expression and control. Statistically significant correlation was revealed between teacher's rationality, emotionality, and experience in problem-solving and self-reflection and insight while teachers' intuition in problem-solving had no statistically significant correlations with self-reflection. Statistically significant correlation was revealed between teacher's anger expression and control and self-reflection, and 
insight while anger expression and control had no statistically significant correlations with engagement in self-reflection.

\section{The relationships of teachers' problem-solving, anger expression and control,} self-reflection and insight in terms of their age and working experience

A positive correlation was identified between the age of participants and external anger control $(r=0.27, p=0.01)$, insight $(r=0.41, p=0.01)$ and imagination while solving problems $(\mathrm{r}=0.19, \mathrm{p}=0.05)$. A weak negative correlation between the age and anger expression index $(r=-0.23 ; \mathrm{p}=0.05)$ was established. Working experience positively significantly correlated with external anger control $(\mathrm{r}=0.26, \mathrm{p}=0.01)$, insight $(\mathrm{r}=0.34$, $\mathrm{p}=0.01)$ and imagination while solving problems $(\mathrm{r}=0.17, \mathrm{p}=0.05)$. However, these correlations were not strong.

A separate analysis of relationships between in-service teachers' working experience and the above-mentioned variables disclosed negative correlations between working experience and trait-anger $(\mathrm{r}=-0.31, \mathrm{p}=0.05)$ as well as between working experience and internal anger expression $(r=-0.29, \mathrm{p}=0.05)$. The anger expression index of in-service teachers is lower compared to that of prospective teachers, but higher external anger control is typical of the latter. The anger expression index gets weaker with age, whereas external anger control tends to grow as working experience and age increase.

\section{The results of regression analysis}

Carrying out further analysis, attempts were made to identify the variables that can help to forecast the total value of anger expression index (AEI) for teachers. A linear regression model was devised, which indicates a dependence of anger expression index on other variables. The model comprised four statistically significant independent variables that predicted AEI: rationality (R), emotionality (E), need for self-reflection (NS), and insight (I). The obtained linear regression model explains $26.3 \%$ of the variance of anger expression index. The conditions of multicollinearity and heteroscedasticity were satisfied. The following regression equation was obtained: $\mathrm{AEI}=58.3-0.34^{\star} \mathrm{R}+0.51^{\star} \mathrm{E}-$ $0.34^{\star} \mathrm{NS}-0.53^{\star} \mathrm{I}$.

According to the signs of a regression equation, a higher value of emotionality increases the probability of higher anger expression index and higher values of rationality, a need for self-reflection and insight may result in a greater probability of lower anger expression index. The assessment of standardized beta coefficients disclosed that insight (0.527) and emotionality (0.523) play the most significant role (only of opposite signs) for anger expression index.

It was hypothesized that the teachers' emotionality in problem-solving and insight predict their anger expression index. The hypothesis was confirmed. The anger expression 
index which reveals the strength of teachers' anger and its possible expression through aggressive actions was strongly predicted by teachers' emotionality in problem-solving and insight.

\section{Discussion}

There is strong "taboo" against teachers' anger in the classroom and sometimes it is denied or remains hidden. The results of our research are expected to be useful in recognizing the problem of teachers' anger in the education system and searching for ways to resolve it. We determined that the total anger expression index is higher among prospective teachers compared to in-service teachers, i.e. the anger of the latter is stronger and more intensive. The prospective teachers could be better prepared to deal with their anger in the classroom by attending special seminars or courses. It is necessary to note that statistically significant differences were not identified between the problemsolving of prospective and in-service teachers. The analysis of relationships of teachers' problem-solving, anger expression and control, self-expression and insight uncovered the positive significant correlation between the teachers' rationality in problem-solving and engagement in self-reflection, need for self-expression, and insight. Training prospective (and in-service) teachers to solve the problems rationally rather than emotionally would be a good means to reduce the outbreaks of teacher anger in the classroom.

Karagun (2015) disclosed that external anger of fourth-year female students increased statistically significantly compared with that of the first-year students. The majority of teachers stated that they experience long-term anger that is related to observable body senses. This leads to changes in the classroom behaviour, inefficient stress coping strategies are selected, teachers face concentration difficulties and learners frequently become direct objects of their anger and disappointment (Sutton, 2007).

The correlation analysis unveiled that the teachers' external anger control positively correlated with age and working experience, i.e. the elder the teachers were, and the longer their working experience was, the more their external anger control was expressed. Following the research of other authors, anger control has positive consequences on personality and facilitates adaptation to life. Rice and Howell (2006) established that anger control helps to reduce anger, whereas weak anger control may lead to various behavioural problems. According to Roulston et al. (2005), teachers with bigger working experience are less vulnerable compared to novice ones. Thus, the elder teachers with more extensive working experience are distinguished by a better developed ability to control anger and to adapt.

The comparison of prospective and in-service teachers' self-reflection and insight disclosed that the insight of in-service teachers was stronger expressed compared to that of prospective teachers. The received data are similar to the results received by other 
researchers. The research conducted by Kepalaite (2010) revealed that the participants with higher educational background demonstrated weaker engagement in self-reflection. Young adults expressed their engagement in self-reflection and the need for self-expression, whereas stronger expression of insight was observed among mature adults. After the longitudinal research, Pai (2019) noticed that the participants, who undertook a special 6-month program for self-reflection development, improved their insight level as well. Lamb (2017) emphasized that self-reflection and insight of teachers were improved by positive feedback from their senior colleagues.

In the present research state-anger was more expressed among women teachers than among men. Such results are in line with the data of other researchers: women in general are slightly angrier than men, but the former is able to better verbalize their sense of anger, whereas men tend to express their anger through aggressive actions more. Women are also generally more prone to internal anger and anger control, whereas external anger is more characteristic of men. Female teachers comprised the bigger part of research participants and this also complied with the research conducted by Petrulyte், Navaitienè and Rimienè, (2017); Sigfusdottir, Farkas and Silver (2004), and Lewis and Haviland-Jones (2004).

The comparison of self-reflection and insight of male and female teachers allowed establishing significantly higher insight among female teachers than among their male colleagues. The identified difference is substantiated by the research on evolutionary differences in women's and men's ability to foresee and to apply insight carried out by Ring et al. (2016). Else-Quest et al. (2012) stated that emotional experience of women's self-efficacy is richer than that of men. Xu, Kang and Guo (2014) made a conclusion that women's insight is better. It was also established that female teachers tend to employ more intuition while solving problems than male teachers.

Weak statistically significant correlations were identified between rationality and emotionality in problem-solving and the majority of anger expression variables. Experience in problem-solving (summative emotionality, imagination, and intuition variable), trait-anger, and internal anger expression correlated significantly positively.

Positive correlations were established between teachers' rationality in problem-solving and self-reflection. Kvanvig (2014) stated that self-reflection in a certain situation helps to choose the most appropriate attitude, which facilitates successful problem-solving. Self-reflection is frequently connected to planning and solution-making. Dishon et al. (2017) used the concept of self-reflective reasoning, whereas Christensen (2010) relied on the concept of rational reflection. The teachers' emotionality, imagination, and experience in problem-solving correlated with engagement in self-reflection and the need for self-reflection. Problem-solving is the ability to make potentially efficient decisions. Employment of emotions while making such decisions is inevitable. Vesely-Maillefer and Saklofske (2018) explained possibilities for the development of emotional intelligence 
while educating new generation teachers as well as its relationships with the satisfaction of the need for self-reflection.

The research conducted by Pukinskaite and Guogienè (2010) showed that external and internal anger was positively significantly linked to emotional and behavioural problems of senior adolescents: strongest relationships were found between external anger expression and external behavioural difficulties and aggressive behaviour. The above-mentioned research on anger expression index showed a negative correlation with social competence and empathy, whereas more intensive anger (state and trait) reactions were more characteristic of the participants with stronger anger expression.

The present research disclosed that stronger expressed anger of teachers led to worse insight and the better the teachers controlled their anger, the stronger was their need for self-reflection and vice versa. Anger is a natural response to stressful situations and the strength of its expression is connected to the level of stress experienced at that time. Leary (2003) acknowledged that a wish to self-reflect is associated with emotional experience and simultaneously with anger as well. Insight helps to analyse reasons for events that evoke anger and reactions to them. However, it was proved that negative emotions (as well as anger) deteriorate the quality of insight (Martin, Del-Monte, Graziani, 2019; Cooper, 2018).

Having applied several models of regression analysis it was established that rationality, the need for self-reflection and insight had a negative effect on anger expression index, whereas their effect on emotionality was positive. The research results allowed assuming that teachers' anger management, self-reflection and problem-solving are significant for their professional development and possibly for their psychical health. The involvement of more teachers in the research or conducting the longitudinal research would help to identify more diverse relationships of different teachers' abilities. The teachers who are entering the profession should be adequately equipped with their teaching abilities. In our research we revealed that abilities of problem-solving, anger control, and self-reflection as well as their relationships could work as facilitators of the professional path of teachers.

It would be also important to investigate the relationships between teachers' problemsolving, anger control, and self-reflection with some personality dimensions or teachers' social emotional health as an important prerequisite for their psychological well-being and the quality of teacher's professional performance. It would be significant to develop the abilities of rational problem-solving, self-reflection, and anger management for in-service teachers in qualification programmes and to include the development of such abilities in the study programmes for prospective teachers. In designing new teacher education programmes, the aim should be not to increase the amount of knowledge but to develop the professional abilities, including problem-solving, anger control and self-reflection.

The conducted research has the following limitations: our research could include a larger and more representative sample, because there is a certain disproportion between women and men and between prospective and in-service teachers in the sample. Prior 
to performing regression the correlation analysis was conducted separately with both groups (prospective teachers and in-service teachers). The tendencies of correlations were similarly so the regression analysis was performed with both groups together. The confirmatory factor analysis of teacher's dimensions should be carried out in our future research. The Lithuanian norms of questionnaire scales are not available, and another instrument for research on anger dimensions could have been used. After all the validation and adaptation procedures of the tools in Lithuania, school psychologists will be able to apply the version adapted in practice.

\section{Conclusions}

Teachers' rationality, emotionality, and experience in problem-solving are related to anger expression and control, self-reflection, and insight.

In-service teachers' external anger control and insight are stronger than in prospective teachers, while anger expression index is higher in prospective teacher.

Teachers' emotionality in problem-solving and insight predicts the strength of teachers' anger and its possible expression through aggressive actions.

Thanks are expressed to Virginija Guogiene, who provided help collecting the data from in-service teachers.

\section{References}

Bardach, L., \& Klassen, R. M. (2020). Smart teachers, successful students? A systematic review of the literature on teachers' cognitive abilities and teacher effectiveness. Educational Research Review, 30, [100312]. https://psyarxiv.com/nt7v9

Bubelienè, D., \& Merkys, G. (2010). Bandymas žvelgti ị pedagogų profesinį stresą kompleksiškai: empirinio tyrimo duomenys. Mokytoju ugdymas, 14(1), 88-102.

Bubnys, R. (2012). Reflektyvaus mokymo(si) metodu diegimo aukštojoje mokykloje metodika: refleksija kaip besimokančiuju asmeninès ir profesinés raidos didaktinis metodas. Šiauliai: Šiaulių valstybinè kolegija.

Bulotaitè, L., \& Lepeškienè, V. (2006). Mokytojų stresas ir jo įveikos strategijos. Pedagogika, 84, $48-52$.

Burić, I., \& Frenzel, A. (2019). Teacher anger: New empirical insights using a multi-method approach. Teaching and Teacher Education, 86, 102879. doi.org/10.1016/j.tate.2019.102895

Chan, A., Chen, K., \& Chong, E. (2010). Work Stress of Teachers from Primary and Secondary Schools in Hong Kong. Lecture Notes in Engineering and Computer Science. 2182. Chine: Hong Kong. 
Christensen, D. (2010). Rational reflection. Philosophical Perspectives, 24, 121-140.

Counell, M., Sheridan, K., \& Gardner, H. (2003). On abilities and domains. In R. Sternberg \& E. Grigorenko (Eds.), The psychology of abilities, competences and expertise (pp. 126-155). Cambridge: Cambridge University Press.

Civitillo, S., Juang, L., Badra, M., \& Schachner, M. (2019). The interplay between culturally responsive teaching, cultural diversity beliefs, and self-reflection: A multiple case study. Teaching and Teacher Education, 77, 341-351.

Cooper, B. (2018). Anger management: The complete psychologist's guide to recognizing and controlling anger: Develop emotional self-awareness and eliminate anxiety, stress and depression. Editorial: Independently published.

Davis, A., \& McDonald, D. (2019). Teachers' reflections of instructional effectiveness: selfassessment through a standards-based appraisal process. Reflective Practice, 20(1), 125-141.

Dishon, N., Oldmeadow, J., Critchley, C., \& Kaufman, J. (2017). The effect of trait self-awareness, self-reflection, and perceptions of choice meaningfulness on indicators of social identity within a decision-making context. Frontiers in Psychology, 8, Article 2034. https://doi.org/10.3389/ fpsyg.2017.02034

Else-Quest, N., Higgins, A., Allison, C., \& Morton, L. (2012). Gender differences in self-conscious emotional experience: A meta-analysis. Psychological Bulletin, 138(5), 947-981.

Epstein, S. (2003). Cognitive-experiential self-theory of personality. In T. Millon, \& M. Lerner (Eds), Handbook of psychology (pp. 159-184). New Jersey: Wiley.

Farrell, T. (2018). Operationalizing reflective practice in second language teacher education. Journal of Second Language Teacher Education, 1(1), 1-20.

Felmer et al. (2019). Teachers' mathematical tensions surfacing during the first session of a problem-solving professional development workshop. In P. Felmer, P. Liljedahl, \& B. Koichu. (Eds.), Problem-solving in mathematics instruction and teacher professional development (pp. 359-378). New York: Springer.

Grant, A. (2001). Rethinking psychological mindedness: Metacognition, self-reflection, and insight. Behaviour Change, 18(1), 8-17.

Grant, A., Franklin, J., \& Langford, P. (2002). The self-reflection and insight scale: A new measure of private self-consciousness. Social Behavior and Personality: An International Journal, 30(8), 821-835.

Howard, S., \& Johnson, B. (2004). Resilient teachers: resisting stress and burnout. Social Psychology of Education: An International Journal, 7(4), 399-420.

Huang, X., Chi-Kin Lee, J., \& Frenzel, A. (2020). Striving to become a better teacher: Linking teacher emotions with informal teacher learning across the teaching career. Frontiers in Psychology, 11, 1067. doi: 10.3389/fpsyg.2020.01067

Karagün, E. (2015). Examination of anger levels of prospective teachers of physical education and sports. Procedia - Social and Behavioural Sciences, 174, 3108-3114.

Kepalaitè, A. (2010). Socialinių pedagogų savirefleksijos ir įžvalgos ypatumai. Specialusis ugdymas, $1(22), 25-32$. 
Körkkö, M., Kyrö-Ämmälä, O., \& Turunen, T. (2016). Professional development through reflection in teacher education. Teaching and Teacher Education, 55, 198-206.

Kvanvig, J. (2014). Rationality and reflection: How to think about what to think. Baylor University: University Press Scholarship Online.

Lamb, J. (2017). How do teachers reflect on their practice? A study into how feedback influences teachers' reflective practice. The STeP Journal, 4(4), 94-104.

Leary, M. (2003). The self and emotion: The role of self-reflection in the generation and regulation of affective experience. In R. Davidson, K. Scherer, \& H. Goldsmith (Eds.), Handbook of affective sciences (pp. 773-786). Oxford University Press.

Lewis, M., \&Haviland-Jones, J. (2004). Handbook of emotions. New York, London: The Guilford Press.

Martin, S., Del-Monte, J., Graziani, P. (2019). Impulsivity issues in borderline personality disorder and its links with insight: the role of urgency. Heliyon, 5 (10), e02564.

Merkys, G. ir Balčiūnas, S. (2019). Dalyko mokytojų ir švietimo pagalbos specialistu poreikis Lietuvos mokyklose (2019 m.): multimetodinè trianguliacinè studija: [rankraštis]. Kaunas, Šiauliai. https://svietimas.vdu.lt/vdu-mokslininku-tyrimas-kelia-klausimus-kas-ugdys-saliesmoksleivius/

Naeimi, L., Abbaszadeh, M., Mirzazadeh, A., Reza Sima, A., Nedjat, S., \& Mortaz Hejri, S. (2019). Validating self-reflection and insight scale to measure readiness for self-regulated learning. Journal of Education and Health Promotion, 8, 150-157.

Navaitienė, J., \& Jaruševičienė, V. (2018). Mokytojų asmenybės bruožai ir pyktis. Pedagogika, 132(4), 23-41

Norris, P., \& Epstein, S. (2011). An experiential thinking style: Its facets and relations with objective and subjective criterion measures. Journal of Personality 79 (5), 1043-1080.

Nystrup, G. (2019). Anger in the classroom. New York: Epigraph Publishing.

Opeyemi, S. M. (2016). Hardiness, sensation seeking, optimism and social support as predictors of stress tolerance among private secondary school teachers in Lagos state. Psychologia, 25(2), 366-382.

Orgoványi-Gajdos, J. (2016). Teachers' professional development on problem-solving. Rotterdam: Sense Publishers.

Pacini, R., \& Epstein, S. (1999). The relation of rational and experiential information processing styles to personality, basic beliefs, and the ratio-bias phenomenon. Journal of Personality and Social Psychology, 76(6), 972-987.

Pai, H. C. (2015). The effect of a self-reflection and insight program on the nursing competence of nursing students: A longitudinal study. Journal of Professional Nursing, 31(5), 424-431.

Papathanasiou, I. V., Tsaras K., Neroliatsiou A., \& Roupa A. (2015). Stress: concepts, theoretical models and nursing interventions. American Journal of Nursing Science, 4(2), 45-50.

Petrulytè, A., Navaitienè, J., \& Rimienè, V. (2017). Būsimųjų pedagogų (universiteto studentų) pykčio ekspresija ir valdymas, problemų sprendimas ir savirefleksija. Ugdymo psichologija, $28,22-37$. 
Pukinskaitė, R., \& Guogienè, V. (2010). Vyresniųjų paauglių pykčio ekspresijos ir kontrolès bei psichosocialinių sunkumų analizè. Visuomenès sveikata, 2(49), 104-113.

Rice, M., \& Howell, C. (2006). Differences in trait anger among children with varying levels of anger expression patterns. Journal of Child and Adolescent Psychiatric Nursing, 19(2), 51-61.

Ring, P., Neyse, L., David-Barett, T., \& Schmid, U. (2016). Gender differences in performance predictions: Evidence from the cognitive reflection test. Frontiers in Psychology, 7, 1680. doi. org/10.3389/fpsyg.2016.01680

Roulston, K., Legette, R., \& Womack, S. T. (2005). Beginning music teachers' perceptions of the transition from university to teaching in schools. Music Education Research, 7(1), 59-82.

Saadati, F., Cerda, G., Giaconi, V., Reyes, C., \& Felmer, P. (2018). Modelling Chilean mathematics teachers' instructional beliefs on problem-solving practices. International Journal of Scientific and Mathematic Education, 17(5), 1009-1029.

Santos-Trigo, M., \& Reynes-Martinez, I. (2019). High school prospective teachers' problem-solving reasoning that involves the coordinated use of digital technologies. International Journal of Mathematical Education in Science and Technology, 50(2), 182-201.

Seitova, M. (2019). Student teachers' perceptions of reflective practice. International Online Journal of Education and Teaching, 6(4), 765-772.

Sigfusdottir, I., Farkas, G, \& Silver, E. (2004). The role of depressed mood and anger in the relationship between family conflict and delinquent behaviour. Journal of Youth and Adolescence, 33(6), 509-522.

Silvia, P., \& Phillips, A. (2011). Evaluating self-reflection and insight as self-conscious traits. Personality and Individual Differences, 50(2), 234-237.

Soemantri, D., Mccoll, G., \& Dodds, A. (2018). Measuring medical students' reflection on their learning: modification and validation of the motivated strategies for learning questionnaire (MSLQ). BMC Medical Education, 18, 274- 284.

Spielberger, C. D., Sydeman, S. J., Owen, A. E., \& Marsh, B. J. (1999). Measuring anxiety and anger with the State-Trait Anxiety Inventory (STAI) and the State-Trait Anger Expression Inventory (STAXI). In M. E. Maruish (Ed.), The use of psychological testing for treatment planning and outcomes assessment (pp. 993-1021). New York: Lawrence Erlbaum Associates Publishers.

Stein, D., \& Grant, A. (2014). Disentangling the relationships among self-reflection, insight, and subjective well-being: The role of dysfunctional attitudes and core self-evaluations. Journal of Psychology, 148(5), 505-22.

Sternberg, R. (1985). Beyond IQ: A Triarchic theory of human intelligence. Cambridge: Cambridge University Press.

Sutton, R. (2007). Teachers' anger, frustration, and self-regulation. In P. A. Schutz, R. Pekrun (Eds.), Emotion in education (pp. 259-274). San Diego: Academic Press.

Tahseen, N. (2015). Work-related stress among teacher-educators: evidence from Punjab. Pakistan Journal of Psychological Research, 30(2), 357-375. 
Taylor, L., \& Newberry, M. (2018). Self-study of a teacher's practices of and experience with emotion regulation: Being and becoming through reflection and engagement. Studying Teacher Education, 14(3), 296-307.

TALIS. (2018). The OECD Teaching and Learning International Survey. http://www.oecd.org/ education/talis/

Taxer, J., Becker-Kurz, B., \& Frenzel, A. (2019). Do quality teacher-student relationships protect teachers from emotional exhaustion? The mediating role of enjoyment and anger. Social Psychology of Education, 22, 209-226.

Tsivgiouras, S., Belias, D., Aspridis, G., \& Mantas, C. (2019). Stress in teaching during a time of crisis: An investigation of the school teachers in Magnisia, Greece.International Journal of Educational Inovation, 1, 164-171.

Vesely-Maillefer, A., \& Saklofske, D. (2018). Emotional intelligence and the next generation of teachers. In K. Keefer, J. Parker, D. Saklofske (Eds.), Emotional intelligence in education: Integrating research with practice (pp. 377-402). New York: Springer International Publishing.

$\mathrm{Xu}, \mathrm{X}$., Kang C., \& Guo, T. (2014). The effects of gender and self-insight on early semantic processing. PLoS ONE, 9(12), el14421. https://doi.org/10.1371/journal.pone.0114421

Žibėnienė, G., \& Barkauskaitè, M. (2018). Būsimųjų pedagogų reflektavimo patirtys kaip profesinio tobulejimo priemonè. Pedagogika, 130(2), 64-75.

\section{Būsimųjų ir dirbančių pedagogų problemų sprendimo, pykčio ekspresijos ir kontrolès, savirefleksijos ir įžvalgos}

\section{sąsajos}

Ala Petrulyte் ${ }^{1}$ Julita Navaitiené ${ }^{2}$, Vaiva Rimiené $\dot{~}^{3}$

\footnotetext{
Vytauto Didžiojo universitetas, K. Donelaičio g. 58, 44248 Kaunas, ala.petrulytė

Vytauto Didžiojo universitetas, K. Donelaičio g. 58, 44248 Kaunas, julita.navaitiene@vdu.lt

Vytauto Didžiojo universitetas, K. Donelaičio g. 58, 44248 Kaunas, vaiva.rimienė@vdu.lt
}

\section{Santrauka}

Straipsnyje pristatomas būsimųjų ir dirbančių pedagogų problemų sprendimo, pykčio ekspresijos ir kontrolès, savirefleksijos ir įžvalgos raiškos ir sąsajų tyrimas. Nors pedagogų problemų sprendimo gebejimų raiškos, neigiamų emocijų ir profesinès veiklos savirefleksijos atskiri aspektai yra tirti, tačiau jų sąsajos tyrinètos itin mažai. Tyrimo tikslas - ištirti dirbančių ir būsimųjų mokytojų problemų sprendimo, pykčio ekspresijos ir kontrolès, savirefleksijos ir ¡̨žvalgos sąsajas. Tyrimo metodikos: problemų sprendimas (Pacini ir Epstein, 1999); pykčio ekspresija ir kontrolè (Spielberger ir kt., 1999), savirefleksijos ir įžvalgos skalè (Grant ir kt., 2002). 
Tiriamieji: 160 būsimųjų pedagogų (aukštųjų mokyklų studentai) ir dirbantys pedagogai (ịvairių mokyklų). Tyrimo rezultatai ir išvados. Visų trijų metodikų Cronbach alfa svyruoja nuo 0,70 iki 0,88 , jų vidinį nuoseklumą galima laikyti pakankamu. Nustatyti teigiami ryšiai sprendžiant problemas tarp pedagogų racionalumo, savirefleksijos ir pykčio kontrolès, taip pat tarp pykčio ekspresijos ir emocionalumo. Atlikus regresinę analizę, nustatyta, kad pedagogų racionalumas sprendžiant problemas, savirefleksijos poreikis bei ịžvalga turi įtaką tiek išorinei, tiek vidinei pykčio kontrolei. Problemų sprendimas, pykčio valdymas ir savirefleksija galimai yra reikšmingi pedagogo profesinei raidai ir psichinei sveikatai.

Esminiai žodžiai: pedagogai, problemų sprendimas, pykčio ekspresija ir kontrole, savirefleksija, ižvalga. 